УДК 330.3

DOI: https://doi.org/10.32782/2224-6282/161-11

\begin{abstract}
Нікітенко К. С.
кандидат економічних наук, доцент,

ДВНЗ «Херсонський державний аграрний університет» ORCID: https://orcid.org/0000-0001-8423-5605
\end{abstract}

Жосан Г. В.

кандидат економічних наук, доцент, ДВН3 «Херсонський державний аграрний університет» ORCID: https://orcid.org/0000-0002-3577-6701

Nikitenko Kateryna, Zhosan Hanna Kherson State Agrarian University

\begin{abstract}
У статті розглянуто технології роботи з великими даними, проаналізовано результати опитування Тесһ Рго Research про застосування великих даних, побудовано технологічну екосистему Інтернету речей. Встановлено, изо оцифровка - ие вже реальність, а проникнення Інтернету та циифрових технологій у традиційні галузі стало однією з головних тенденцій останніх років і відбувається в глобальному маситабі, шуо дає змогу говорити про изифрову трансформацію всіх галузей економіки, життя суспільства та формування нового економічного способу жстття - ичифрової економіки. Практичне використання технологій иуифрової економіки - ие сучасна тенденція у соціально-економічному житті сучасної держави, яка активно впливає на поведінку споживачів, проявляється у мобільності та прагненні компаній до постійного вдосконалення.
\end{abstract}

Ключові слова: иџифрові технологї̈, хмарні обчислення, великі дані, Інтернет речей.

\title{
DETERMINING THE ROLE OF BIG DATA IN DECISION-MAKING IN THE ECONOMY AND FINANCE
}

Consulting agency PricewaterhouseCoopers has identified eight key technologies for the digital economy: the Internet of Things and artificial intelligence - the foundation for a new generation of digital resources; robotics, drones and $3 D$ printers - devices that help transfer the capabilities of a computer to the material world; virtual reality is also augmented - technologies that combine the physical and digital worlds; blockchain and cloud computing - a new approach to basic business accounting operations. Analysis of recent research and publications. The topic of big data is still controversial, although it is being studied by specialists in various fields (economics, information technology, politics, and others). The influence of big data on social processes and business organization, in particular, was studied by Bill Franks, Victor Mayer-Schonberger, Kenneth Kukier, Eric Siegel, John Foreman and others. Publicistic materials prevail among domestic sources, but there is a lack of fundamental works in this direction. Purpose of the article. explore the essence and practical application of revolutionary digital technologies - cloud computing, big data and the Internet of things. The article identifies the advantages and disadvantages of cloud technologies, forms a model of cloud services, discusses technologies for working with big data, analyzes the results of a Tech Pro Research survey on the use of big data, and builds a technological ecosystem of the Internet of Things. Digitization is already a reality, and the penetration of the Internet and digital technologies into traditional industries has become one of the main trends in recent years and is taking place on a global scale, which allows us to talk about the digital transformation of all sectors of the economy, social life and the formation of a new economic structure - the digital economy. The practical use of digital economy technologies is a modern trend in the socio-economic life of a modern state, actively influences consumer behavior, manifests itself in mobility and the desire of companies for continuous improvement.

Keywords: digital technologies, cloud computing, big data, Internet of things.

Постановка проблеми. Консультаційне агентство Pricewaterhouse Coopers визначило вісім ключових технологій цифрової економіки: Інтернет речей та штучний інтелект - фундамент для нового покоління цифрових ресурсів; робототехніка, безпілотники та 3D-принтери - пристрої, що сприяють передачі можливостей комп'ютера в матеріальний світ; доповнена та віртуальна реальність - технології, що поєднують фізичний та цифровий світи; блокчейн та хмарні обчислення - новий підхід до основних операцій ведення обліку комерційних операцій.

Аналіз останніх досліджень і публікацій. Тема великих даних є досі неоднозначною, хоча вивчається спеціалістами в різних галузях (економіка, інформа- ційні технології, політика та ін.). Вплив big data на суспільні процеси та організацію бізнесу досліджували Білл Френкс, Віктор Майєр-Шонбергер, Кеннет Кук'єр, Ерік Сігель, Джон Форман та ін. Серед вітчизняних джерел переважають матеріали публіцистичного характеру, проте відчувається нестача фундаментальних праць у цьому напрямі.

Мета статті полягає у вивченні суті та практичного застосування революційних цифрових технологій великих даних та Інтернету речей.

Виклад основного матеріалу. Термін «великі дані» 3'явився наприкінці 1990-х років серед учених, які не могли дозволити собі зберегти чи проаналізувати величезні та зростаючі дані, отримані все більш 
досконалими цифровими технологічними інструментами, що використовуються для вирішення проблем фізики частинок, економіки, кліматології, астрофізики тощо. Загалом великі дані означають дані, які користувачам важко обробляти через їх великий обсяг і для яких потрібні спеціальні інструменти.

Велика кількість інформації - не єдина характеристика великих даних. Дослідники у галузі великих даних, як правило, виділяють такі характеристики:

- обсяг - обсяги інформації, які вимірюються в терабайтах, петабайтах тощо;

- швидкість - висока швидкість як появи, так i накопичення нової інформації й обробки величезних обсягів різноманітної інформації до роботи в режимі реального часу;

- різноманітність - збирається, обробляється та зберігається як структурована, так і неструктурована інформація, яка надходить із різних типів джерел;

- надійність - забезпечення надійності зібраних даних із погляду їх належності до конкретного об'єкта моніторингу.

Для роботи з великими обсягами цифрових даних використовуються різні технології (рис. 1).

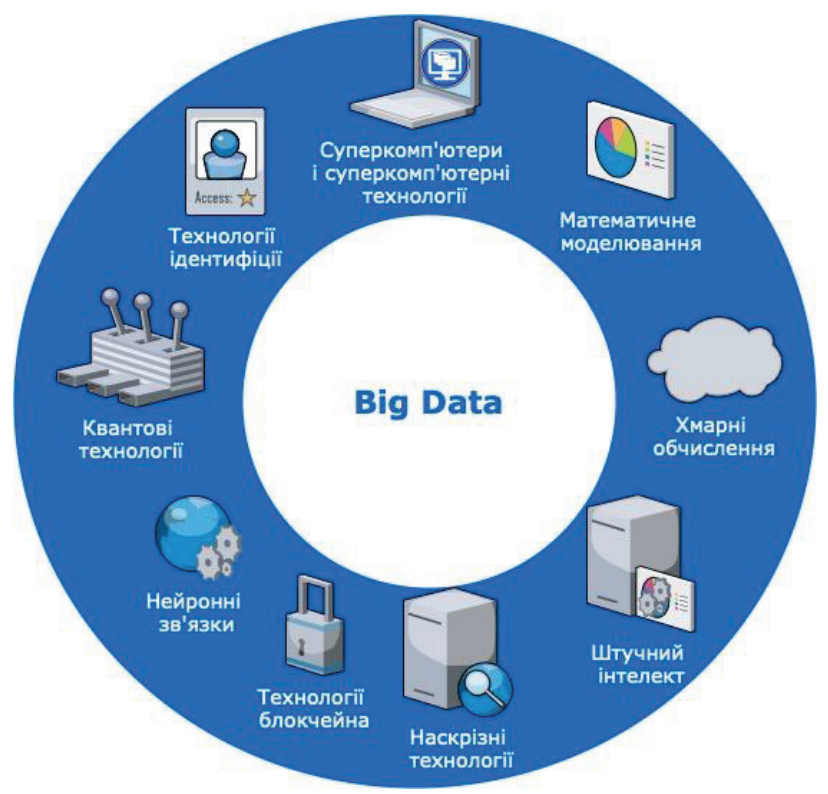

Рис. 1. Технології роботи 3 великими даними

Зростання інтересу до технологій великих даних за останні кілька років пояснюється двома основними чинниками. По-перше, це швидке розширення використання комп'ютерів та різних цифрових пристроїв не лише у бізнесі, а й у повсякденному житті великої кількості людей. У транспорті, промисловості, торгівлі та охороні здоров'я використовується все більше датчиків і сенсорних пристроїв, які відповідають за збір і передачу даних про рух вантажів, транспортну ситуацію та стан пацієнта. Як результат, формується новий простір, в якому об'єкти реального та віртуального світів спілкуються один 3 одним за допомогою дротового та бездротового каналів зв'язку (так званий Інтернет речей). По-друге, популярність великих даних пов'язана зі збільшенням інформаційних потоків в Інтернеті, які включають твіти, публікації у соціальних мережах, запити до пошукових систем, дані сенсорів та контролерів мільйонів розумних пристроїв.

Першими компаніями, які зрозуміли приховану цінність великого обсягу інформації, були Google, Amazon, Yahoo, Facebook, де були розроблені інструменти для збору, аналізу та зберігання великих обсягів даних. Розроблення хмарних рішень призвела до збільшення кількості центрів обробки даних та зниження вартості їхніх послуг, що, своєю чергою, значно знизило витрати компаній на зберігання інформації.

Опитування показало, що найширше застосування технологій великих даних було знайдено в телекомунікаціях, а також у галузі машинобудування, страхування та фінансів (рис. 2).

Провідні галузі використання великих даних - це роздрібна торгівля, фінанси, охорона здоров'я та телекомунікації.

Нині великі дані стали розглядатись як ефективний інструмент для прийняття урядових рішень. Одним зі способів роботи з великими даними щодо регулювання соціально-економічних та політичних процесів є складання та аналіз офіційної статистики виключно на їх основі та в поєднанні з традиційними джерелами: регістрами, опитуваннями тощо.

Консультаційний відділ Cisco IBSG оцінює між 2008 і 2009 рр. Кількість об'єктів, підключених до Інтернету, перевищила кількість людей, таким чином, відбувся еволюційний перехід від Інтернету людей до Інтернету речей.

Інтернет речей розуміється як інформаційна взаємодія в Інтернеті, яка включає взаємодію фізичних пристроїв, транспортних засобів, будівель та інших об'єктів, вбудованих в електроніку, програмне забезпечення, датчики, пускачі та мережі, що дають змогу цим об'єктам збирати та обмінюватися даними.

На відміну від класичного Інтернету, який забезпечує спілкування між людьми, Інтернет речей забезпечує машинно-машинний зв'язок між неживими речами, а також між неживим та оживленим світами, між речами та людиною, інформуючи останнього про те, що відбувається в кімнатах, квартирах, будинку, на фабриках, складах, відкритій території, та прийняття відповідних рішень від людини у вигляді сигналів для виправлення ситуації.

Інтернет речей передбачає підключення предметів домашнього вжитку до глобальної комп'ютерної мережі за допомогою вбудованих модулів зв'язку, завдяки яким вони здатні взаємодіяти між собою, зовнішнім середовищем, обмінюватися даними та виконувати операції без утручання людини.

Перелік предметів, якими можна скористатися завдяки цій можливості, необмежений: це можуть бути транспортні засоби, побутова техніка, пристрої зв'язку. Датчики, вбудовані в об'єкти, відстежують поточні процеси в режимі реального часу, вбудовані модулі зв'язку спілкуються $з$ іншими об'єктами по Мережі. За підрахунками, до кінця 2018 р. кількість пристроїв, підключених до ІоТ, у всьому світі досягла 22 млрд. За прогнозами, до 2025 р. до Інтернету буде підключено 38,6 млрд пристроїв, а до 2030 р. - 50 млрд.

Інтернет речей використовується у широкому діапазоні життєвих напрямів: для задоволення соціальних та особистих потреб, в охороні здоров'я, самоплануванні оздоровчої діяльності людиною, для автоматиза- 


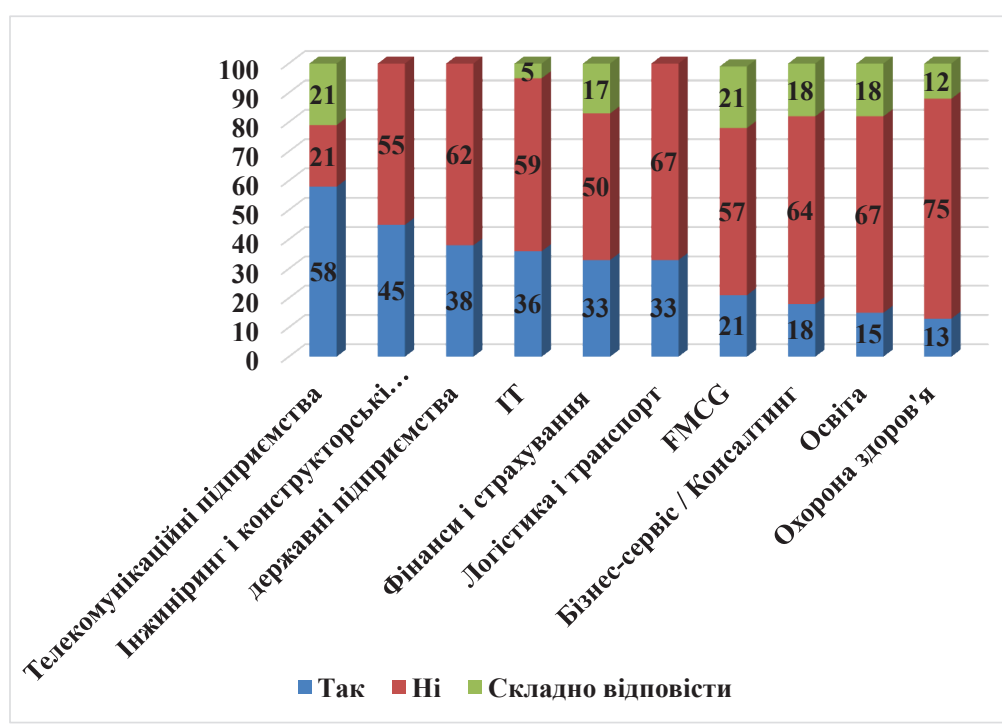

Рис. 2. Результати опитування Tech Pro Research про застосування великих даних

ції повсякденного життя, а також як засоби підтримки особистісного розвитку та моніторингу навколишнього середовища. Подальше застосування технологій IоT змінить обличчя багатьох галузей та сфер життя. У низці сфер людські зусилля та помилки будуть зведені до мінімуму. Наприклад, Інтернет речей в електроенергетиці докорінно змінить технології, забезпечить економію витрат та створить нові продукти в усіх частинах енергетичної системи. У сільському господарстві Інтернет речей дасть змогу запровадити точне землеробство та значно поліпшити управління сільськогосподарським транспортом. Логістичні рішення IоT допоможуть зменшити витрати, збільшити прозорість ланцюга поставок та зменшити використання людської праці. Розумні міські технології створять більш привабливе міське середовище з ефективною транспортною системою, житлово-комунальними послугами, зручною інфраструктурою та забезпечать безпеку населення. Серед компонентів розумного будинку найпопулярнішими серед споживачів є пристрої для підвищення безпеки, моніторинг споживання води та енергії, розумні побутові прилади та термостати.

За даними Глобального інституту МакКінсі, Інтернет речей до 2025 р. приноситиме світовій економіці від 4 до 11 трлн доларів США щорічно.

Проєкт Internet of Things приймається як пріоритетний на державному рівні в СС та Китаї й є ключовим для таких корпорацій, як Cisco, IBM, Intel, Ericsson, Huawei, ZTE, NEC, HP тощо.

Інтернет речей, поступово проникаючи у всі сфери людської діяльності, вніс таке поняття, як «індустріальний Інтернет речей» (IIоT), до числа активно обговорюваних технологічних тенденцій. Промислові технології ІоТ можуть значно знизити витрати та підвищити продуктивність. За результатами опитування найбільших німецьких компаній Pricewaterhouse Coopers було виявлено, що, відповідно до очікувань компаній протя- гом 2019-2022 рр., інвестиції в промислові Інтернет-технології можуть підвищити ефективність у середньому на $18 \%$ та зменшити витрати на 14\%. Водночас Інтернет речей дає змогу промисловим компаніям трансформувати бізнес-моделі та збільшувати дохід від послуг (наприклад, від післяпродажного обслуговування): компанії прогнозують, що в середньому ці технології забезпечуватимуть зростання доходу на $2,9 \%$ щорічно.

За даними аналітиків із Market Research Engine, ринок IIоT зросте із середньорічним темпом понад $8 \%$ і перевищить 176 млрд доларів до 2022 р. Компанія Zion Market Research стверджує, що сектор IoT до 2023 р. досягне 232 млрд доларів. Глобальний ринок оглядає світовий ринок IІоТ (включаючи обладнання, датчики, роботизовані системи, платформи, програмне забезпечення та послуги) до 2023 р. становитиме 700 млрд доларів. За прогнозами дослідницького агентства Machina, до 2025 р. світовий ринок ІІоТ вийде на 484 млрд євро.

Висновки. Таким чином, великі дані $є$ фундаментальним складником цифрової трансформації економіки, а дані - засобом забезпечення нових технологій та інноваційних рішень. Водночас це справжній океан можливостей для моніторингу всього на світі. Новий технологічний рівень отримання нових знань полягає у використанні можливостей, що з'являються в процесі автоматизованого визначення таких кореляційних зв'язків, які були приховані від беззбройного людського інтелекту. Визначення нових кореляційних зв'язків, своєю чергою, дасть змогу обчислити нові причини таких зв'язків, що існують у світі, - отримати нові знання і на їх основі приймати набагато ефективніші рішення.

Поява нових підходів до обробки інформації, у даному разі поширення поняття «великі дані» та використання сучасних технологій цифрового масштабування, призвела до формування глобального електронного носія, відкрила нові підходи до організації та здійснення бізнесу, нові можливості в різних сферах. Використання великих даних - це не лише інструмент оптимального планування та інформації, це - шлях до формування нового майбутнього.

Оцифровка - це вже реальність, а проникнення Інтернету та цифрових технологій у традиційні галузі стало однією 3 головних тенденцій останніх років і відбувається в глобальному масштабі, що дає змогу говорити про цифрову трансформацію всіх галузей економіки, життя суспільства та формування нового економічного способу життя - цифрової економіки. Практичне використання технологій цифрової економіки - це сучасна тенденція у соціально-економічному житті сучасної держави, яка активно впливає на поведінку споживачів, проявляється в мобільності та прагненні компаній до постійного вдосконалення. Paperback. March 4, 2014. 
3. Зибарева О.В., Кравчук І.П. Актуалізація концепції «великі дані» (англ. Big data) в умовах поширення інформаційного суспільства. Економіка. Управління. Інноващії. 2015. № 1(13). URL : http://www.irbisnbuv.gov.ua/cgibin/irbis_nbuv/cgiirbis_64.exe.

4. Dijcks Jean Pierre. Big Data for the Enterprise. Oracle. October, 2011. URL : https://www.oracle.com/technetwork/ database/ bidatawarehousing/wpbigdatawithoracle521209.pdf.

5. Beyer M.A., Laney D. The Importance of Big Data: A Definition. Gartner Inc. Electronic data. Stamford : Gartner, 2012. URL : https://www.gartner.com/en/documents/2057415 (viewed on 1.11.2020). Title from the screen.

6. Золотников Я., Бондарьов О. Друга нафта. В Україні з'явиться онлайн-курс з Big data - найбільш затребуваної у світі IT-професії. Новое Время. 2016. URL: http:// nv.ua/ukr/science/druganaftuvukrajinizjavitsja onlajnkurspobigdatanajbilshzatrebuvan ojuvsviti itprofesiji89806.html (дата звернення: 01.11.2020).

7. Жосан Г.В., Гарафонова О.І., Чікірісов Д.В. Поняття відкритих даних як інструмент підтримки рівня соціальної відповідальності підприємств. Збалансоване управління економічними проиесами в суспільстві та бізнес-середовищі в умовах трансформації сочіально-економічних інституйій : міжнародна колективна монографія / за ред. д.е.н., професора Г.Г. Савіної. Херсон : ПП Вишемирський В.С., 2016. С. 182-188.

8. Yurii Kyrylov, Natalia Kyrychenko, Tatyana Stukan and Hanna Zhosan, Formation of Enterprise Management Strategies and Entrepreneurship Training. International Journal of Management. 2020. № 11(6). P. 793-800. URL : http://www.iaeme.com/ MasterAdmin/Journal_uploads/ijm/VOLUME_11_ISSUE_6/IJM_11_06_067.pdf.

9. Yuriy Kyrylov, Viktoriia Hranovska, Hanna Żhosan, Inna Dotsenko, Innovative Development of Agrarian Enterprises of Ukraine in the Context of the Fourth Industrial Revolution. Solid State Technology. Volume 63 Issue: 6. Publication Year: 2020. P. 1430-1448.

\section{References:}

1. Lynch, C. (2008), "How do your data grow?", Nature, vol. 455, No7209, pp. 28-29.

2. Mayer Schonberger, V. and Cukier, K. (2014), "Big Data: A Revolution That Will Transform How We Live, Work, and Think", New York, USA.

3. Zybareva, O. V. Kravchuk, I. P. (2015), "Actualization the concept of "Big Data" in the distribution of the information society", Ekonomika. Upravlinnia. Innovatsii, [Online], vol. 1 (13), available at: http://www.irbis nbuv.gov.ua/cgibin/irbis_nbuv/cgiirbis_64.exe (Accessed 1.11.2020).

4. Dijcks Jean Pierre. (2011), "Big Data for the Enterprise", Oracle, available at: https://www.oracle.com/technetwork/database/ bidatawarehousing/ wpbigdatawithoracle521209.pdf (Accessed 1.11.2020).

5. Beyer, M. A. and Laney, D. (2012), "The Importance of "Big Data": A Definition", Gartner Inc., available at: https://www.gartner.com/ en/documents/2057415 (Accessed 1 June 2019).

6. Zolotnykov, Ya. and Bondar'ov, O. (2016), "Second oil. In Ukraine there will be an online course on Big data - the most sought after IT profession in the world", Novoe Vremia: elektronnyj zhurnal, available at: http://nv.ua/ukr/ science/druganaftuvukrajinizjavits jaonlajnkurspo bigdatanajbilshzatrebuvanojuvsvitiitprofesiji 89806.html (Accessed 1.11.2020).

7. Zhosan G.V., Garafonova O.I., Chikirisov D.V. (2016) Understand the "given" as to the tool for the development of the level of social development of enterprises. Balancing the management of economic processes in the suspension and business middle ground in the minds of the transformation of social and economic institutions: international collective monograph / ed. Doctor of Economics, Professor G.G. Savinoi. Kherson: PP Vishemirsky V.S.287 p. P. 182-188

8. Yurii Kyrylov, Natalia Kyrychenko, Tatyana Stukan and Hanna Zhosan (2020), Formation of Enterprise Management Strategies and Entrepreneurship Training, International Journal of Management, 11 (6), pp. 793-800. Available from http://www.iaeme.com/ MasterAdmin/Journal_uploads/ijm/VOLUME_11_ISSUE_6/IJM_11_06_067.pdf

9. Yuriy Kyrylov, Viktoriia Hranovska, Hanna Zhosan, Inna Dotsenko (2020), Innovative Development of Agrarian Enterprises of Ukraine in the Context of the Fourth Industrial Revolution. Solid State Technology. Volume: 63 Issue: 6. Publication Year: pp. $1430-1448$. 